DOI https://doi.org/10.18551/rjoas.2018-08.49

\title{
EFFECT OF YOUNG COCONUT WATER AND EGG YOLK EXTENDER RATIO AND LENGTH OF STORAGE AT LOW TEMPERATURE ON SPERM MOTILITY AND VIABILITY OF BALI BULL
}

\author{
Vicente Deonizio* \\ Instituto Politecnico de Betano, Timor Leste \\ Wahjuningsih Sri, Nurul Isnaini \\ Faculty of Animal Husbandry, University of Brawijaya, Indonesia \\ *E-mail: deonizio.vicente@gmail.com
}

\begin{abstract}
The objective of this study was to determine the effect of the different ratio of young coconut water and egg yolk extender and length of storage at low temperature on sperm motility and viability of Bali bull. The method used was an experiment in the completely randomized factorial design. The first factor was young coconut water and egg yolk ratio which consisted of 5 treatments, including P0 (control) $=$ Tris aminomethane, $\mathrm{P} 1=85 \%$ of young coconut water $+15 \%$ of egg yolk, P2 $=80 \%$ of young coconut water $+20 \%$ of egg yolk, $\mathrm{P} 3=75 \%$ of young coconut water $+25 \%$ of egg yolk, $\mathrm{P} 4=70 \%$ of young coconut water $+30 \%$ of egg yolk. The second factor was the length of storage at a low temperature which consisted of 3 treatments, including 1 day, 2 days and 3 days. All treatments were replicated 10 times. Variable measured was sperm motility and viability. Results showed that the sperm motility of Bali bull in P0 (control) after 3 days of storage was $38.00 \%$, which was significantly different $(\mathrm{P}<0.05)$ compared to P1 $(21.50 \%), \mathrm{P} 2(24.50 \%), \mathrm{P} 3(28.00 \%)$, and compared to P4 $(33.50 \%)$. Results also showed that sperm viability of Bali bull in P0 after 3 days of storage, which was in the amount of $65.06 \%$, was significantly greater $(\mathrm{P}<0.05)$ than $\mathrm{P} 1(55.64 \%), \mathrm{P} 2$ $(58.42 \%)$, and P3 $(60.91 \%)$, but did not significantly different $(P>0.05)$ compared to $P 4$ $(63.54 \%)$. The conclusion of this study is that the use of extender which composed of $70 \%$ of young coconut water $+30 \%$ of egg yolk could maintain the sperm motility and viability of Bali bull.
\end{abstract}

\section{KEY WORDS}

Coconut water, egg yolk, length of storage, sperm motility, Bali bull.

Bali cattle breeding are caused by the limited number of superior males and the occurrence of cross-breeding with different breeds or lines as well as uncontrolled breeding in nature, resulting in frequent inbreeding. Therefore, reproductive biotechnology manipulation is needed to maintain the purity of the Bali cattle. One of the manipulations is through artificial insemination (Hastuti, 2008). To support the success of artificial insemination, it is necessary to improve the semen quality using semen extenders to increase the volume, to protect the spermatozoa against cold shock, to supply nutrient sources, to prevent the germs growth, and to maintain osmotic pressure and electrolyte balance (Hadi, 2002).

Egg yolk contains lipoproteins and lecithin which maintains and protects spermatozoa from cold shock. To meet the needs of simple carbohydrates as the energy sources in semen extenders, young coconut water can be used because it contains carbon elements in the form of simple carbohydrates such as glucose, sucrose, and fructose and nitrogen elements in the form of proteins composed of amino acids such as aline, arginine, alanine, and serine (Zakiah, 2009).

Semen extenders should be able to demonstrate the ability to minimize the sperm motility impairment rate to eventually extend the length of storage time. Not all semen extenders exhibit the same ability to maintain spermatozoa. Therefore, it is necessary to 
identify the effect of semen extenders and length of storage on the motility and viability of Bali bull fresh semen.

\section{MATERIALS AND METHODS OF RESEARCH}

This research was conducted in Artificial Insemination Center (Balai Besar Inseminasi Buatan, BBIB) Singosari. The materials used in this research were the fresh semen of 5 Bali bulls with age ranging from 3 - 5 years in Artificial Insemination Center Singosari. Semen was collected twice a week using an artificial vagina. The bulls were placed in individual cages and clinically healthy.

The method used in this study was the experimental laboratory. Semen was stored at cold temperatures with young coconut water and egg yolk extenders. The treatments conducted in this study were 5 treatments with 10 replications.

The design for this research was the Completely Randomized Factorial Design with two factors. The first factor was the young coconut water and egg yolk extender ratio. Treatment $(\mathrm{T})$ consisted of $\mathrm{P0}=$ Tris aminomethane, $\mathrm{P} 1=85 \%$ coconut water $+15 \%$ egg yolk, P2 $=80 \%$ coconut water $+20 \%$ egg yolk, P3 $=75 \%$ coconut water $+25 \%$ egg yolk, and $\mathrm{P} 4=70 \%$ coconut water $+30 \%$ egg yolk. The second factor was the length of storage $(\mathrm{L})$ which consisted of 1-day, 2-day, and 3-day storage. The semen used in this study had 50$55 \%$ motility and was divided into 5 parts with the same volume.

Preparation of extenders. Coconut water from young (green) coconuts was poured into an Erlenmeyer flask and filtered using filter paper. Then, coconut water $\mathrm{pH}$ was measured with litmus paper before mixing the extenders, resulting in coconut water $\mathrm{pH}$ of 6.4. It was necessary to neutralize the coconut water $\mathrm{pH}$ before preparation of extenders. Coconut water was inactivated for 20 minutes using a thermo-string at the temperature of $170^{\circ} \mathrm{C}$, while the water temperature in the control remained stable at $56^{\circ} \mathrm{C}$. After the inactivation, 0.6 grams of $\mathrm{NaHCO} 3$ was added into $500 \mathrm{ml}$ of young coconut water and homogenized for 10 minutes. The young coconut water $\mathrm{pH}$ increased to 7.0. Young coconut water was poured into the measuring cup according to the required volume. Egg from the free-range chicken was prepared and egg yolk was separated from egg white with filter paper. Egg yolk was then added to the young coconut water according to each treatment. After mixing the young coconut water with egg yolk, penicillin $1000 \mathrm{IU}$ and $1 \mathrm{mg}$ of streptomycin were added to each $\mathrm{ml}$ of extenders.

Independent and Dependent Variables. The independent variable was the different ratio of young coconut water and egg yolk and length of storage. The dependent variable was the sperm motility and viability of Bali bull.

Data Analysis. Data were analyzed using the ANOVA of SPSS software for windows ver. 23.0 to determine the effect of each treatment on the sperm quality. If there was a significant difference, it was tested further with Duncan's Multiple Range Test (DMRT) to determine the difference between treatments.

\section{RESULTS AND DISCUSSION}

Fresh semen characteristics of Bali bull. The observation results of fresh semen macroscopic and microscopic analysis obtained the average characteristic of Bali Bull fresh semen. Table 1 below presents the results.

Sperm Individual Motility Percentage. Motility is one important factor because motility is a parameter for the semen quality. Motility also determines spermatozoa to penetrate the cervix to the ovum, so fertilization can occur (Carla et al., 2008). The observation results of the sperm individual motility percentage of Bali bull fresh semen during the study are presented in Table 2.

Observation data in Table 2 showed that the highest average value of fresh sperm motility was at the 1-day storage and at P0 (Control) of $48.00 \%$. The lowest motility was at the 3-day storage and at P1 treatment of $21.50 \%$. The results of the analysis of variance indicated that the longer storage time decreased the motility percentage. The data of the 
analysis of variance showed interaction $(P<0.05)$ between extender ratio and length of storage on the sperm motility of Bali bull.

Table 1 - The Mean Value of Fresh Semen Analysis

\begin{tabular}{ll}
\hline Parameter & Mean \\
\hline Volume $(\mathrm{ml})$ & $6.1 \pm 0.61$ \\
Color & Yellowish white \\
Aroma & Distinctive \\
$\mathrm{pH}$ & $6.5 \pm 0.31$ \\
Mass motility & ++ \\
Individual motility (\%) & $55.00 \pm 1.58$ \\
Viability (\%) & $75.38 \pm 3.07$ \\
Abnormality $(\%)$ & $8.66 \pm 0.52$ \\
Membrane integrity $(\%)$ & $74.37 \pm 3.34$ \\
Concentration $\left(10^{6}\right) / \mathrm{ml}$ & $830.4 \pm 81.38$ \\
\hline
\end{tabular}

Source: processed primary data (2018).

Table 2 - The Effect of Length of Storage in Cold Temperature on Sperm Motility

\begin{tabular}{lll}
\hline Day & Treatment & Individual Motility (\%) \\
\hline 1 & P0 & $48.00 \pm 2.58^{\mathrm{a}}$ \\
& P1 & $32.00 \pm 3.49^{\mathrm{d}}$ \\
& P2 & $35.00 \pm 5.27^{\mathrm{d}}$ \\
& P3 & $38.50 \pm 3.37^{\mathrm{c}}$ \\
\hline 2 & P4 & $43.50 \pm 3.37^{\mathrm{b}}$ \\
\hline & P0 & $43.00 \pm 2.58^{\mathrm{a}}$ \\
& P2 & $26.50 \pm 2.41^{\mathrm{e}}$ \\
& P3 & $29.50 \pm 3.68^{\mathrm{d}}$ \\
& P4 & $33.00 \pm 2.58^{\mathrm{c}}$ \\
& P0 & $38.00 \pm 2.58^{\mathrm{b}}$ \\
\hline & P1 & $38.00 \pm 2.58^{\mathrm{a}}$ \\
& P2 & $21.50 \pm 2.41^{\mathrm{e}}$ \\
& P3 & $24.50 \pm 3.68^{\mathrm{d}}$ \\
& P4 & $28.00 \pm 2.58^{\mathrm{c}}$ \\
& & $33.00 \pm 2.58^{\mathrm{b}}$ \\
\hline
\end{tabular}

Notes: P0 (Control) Tris Amino methane, P1 (85\% CW + 15\% EY), P2 (80\% CW + 20\% EY), P3 (75\% CW + 25\% $E Y)$, P4 (70 CW $+30 \% E Y)$. Values with different superscripts within the row differ significantly $(P<0.05)$.

The result of Duncan Test analysis showed that the percentage of young coconut water and egg yolk extender ratio on 2-day storage at P0 (Control) treatment of $43.00 \%$ was significantly different to $\mathrm{P} 1$ of $26.50 \%, \mathrm{P} 2$ of $29.50 \%, \mathrm{P} 3$ of $33.00 \%$, and $\mathrm{P} 4$ of $38.00 \%$. The 3-day storage on P0 (Control) treatment of $38.00 \%$ was significantly different to $\mathrm{P} 1$ of $21.50 \%, \mathrm{P} 2$ of $24.50 \%, \mathrm{P} 3$ of $28.00 \%$, and P4 of $33.00 \%$. The results of the significance difference test indicated that the combination of the extender ratio and the length of storage gave the best response on $\mathrm{P} 4$ treatment $(70 \% \mathrm{CW}+30 \% \mathrm{EY})$. It can be concluded that the use of $70 \%$ young coconut water and $30 \%$ egg yolk extender ratio can be used as a substitution of tris amino methane extenders.

The analysis results of observation data above showed that the longer storage time decreased the motility percentage value. Hine et al. (2014) state the cow sperm motility percentage is affected by the sperm age and the amount of energy available in semen. The older spermatozoa cause the increasing damaged spermatozoa which thereby decreases the motility value. Arifianti and Purwantara (2010) assert the sperm motility percentage is associated with the sperm plasma membrane integrity. If the plasma membrane in the middle part of the spermatozoa is damaged, the aspartate aminotransferase (AspAT) enzyme, which is the main mitochondrial enzyme in ATP production, is dispensed in the cell and mixed with the extenders. The absence of AspAT interferes with ATP production and inhibits the sperm motility.

The length of storage affects the sperm $\mathrm{pH}$. The concentration of lactic acid increases with the length of storage which causes the decreasing extender $\mathrm{pH}$, resulting in sperm 
damage and decrease in the sperm motility percentage (Hine et al., 2014). Increased concentration of lactic acid can disrupt metabolic processes due to increased lipid peroxidation of sperm membrane and increase the permeability of cell membrane, making the cells become damaged and die quickly (Zakiah, 2009).

Coconut water contains carbohydrate compounds acted as reducing sugars, i.e. glucose and fructose, which serve as the energy source for spermatozoa (Hine et al., 2014). Arifiantini et al. (2005) state that in addition to being the energy source, coconut water is also a carbohydrate source, especially fructose which has a dual role as the energy source and extracellular cryoprotectant for spermatozoa against cold shock at $3-5^{\circ} \mathrm{C}$. Sulabda et al. (2010) affirm that the use of young coconut water as the bull sperm extenders can provide physical and chemical supplies to maintain sperm fertility and viability.

Egg yolk contains glucose, proteins, and water- and fat-soluble vitamins which have good viscosity for spermatozoa (Hastuti, 2008). Phospholipids, cholesterol, and Low-Density Lipoproteins (LDL) in the egg yolk protect the spermatozoa against cold shock during the cooling process (Amirta et al., 2007). The combination of carbohydrates with phospholipids and LDL contained in the egg yolk is the potential substrate in supporting the sperm motility and viability (Hine et al., 2014).

Viability Percentage. The observation results of the Bali bull fresh semen viability after the treatment of coconut water and egg yolk extender ratio and length of storage are presented in Table 3.

Table 3 - Bali Bull Fresh Semen Viability

\begin{tabular}{lll}
\hline Day & Treatment & Sperm Viability (\%) \\
\hline 1 & P0 & $70.52 \pm 3.83^{\mathrm{a}}$ \\
& P1 & $61.93 \pm 4.83^{\mathrm{d}}$ \\
& P2 & $64.31 \pm 4.71^{\mathrm{cd}}$ \\
& P3 & $66.21 \pm 4.41^{\mathrm{bc}}$ \\
& P4 & $68.75 \pm 4.13^{\mathrm{ab}}$ \\
\hline 2 & P0 & $67.62 \pm 3.74^{\mathrm{a}}$ \\
& P1 & $58.81 \pm 4.67^{\mathrm{d}}$ \\
& P2 & $61.49 \pm 4.52^{\mathrm{bc}}$ \\
& P3 & $63.78 \pm 4.31^{\mathrm{b}}$ \\
& P4 & $66.02 \pm 3.99^{\mathrm{a}}$ \\
\hline 3 & P0 & $65.07 \pm 3.77^{\mathrm{a}}$ \\
& P1 & $55.65 \pm 4.52^{\mathrm{d}}$ \\
& P2 & $58.43 \pm 4.03^{\mathrm{cd}}$ \\
& P3 & $60.92 \pm 3.88^{\mathrm{bc}}$ \\
& P4 & $63.55 \pm 3.80^{\mathrm{ab}}$ \\
\hline
\end{tabular}

Notes: P0 (Control) Tris Aminomethane, P1 (85\% CW + 15\% EY), P2 (80\% CW + 20\% EY), P3 (75\% CW + 25\% $E Y), P 4(70 \mathrm{CW}+30 \% \mathrm{EY})$. Values with different superscripts within the row differ significantly $(P<0.05)$.

The results of the observation data above showed that the highest average viability value of the extender ratio was obtained at the P0 (Control) treatment with the 1-day storage of $70.52 \%$. The lowest viability percentage value was obtained at the $\mathrm{P} 1$ treatment $(85 \% \mathrm{CW}$ $+15 \% \mathrm{EY}$ ) with the 3-day storage of $55.65 \%$. The observation data showed that the longer storage time decreased the viability value. This was presumably because the storage time of sperm cells was associated with the $\mathrm{pH}$ value of the extender medium. The longer storage time decreased the medium $\mathrm{pH}$ because the concentration of lactic acids increased in the medium. Decreased $\mathrm{pH}$ causes physical and biochemical damage to sperm cells and reduces the viability percentage value (Hine et al., 2014).

The result of variance analysis with Duncan's Test showed that there was no significant interaction $(P>0.05)$ between extender ratio and length of storage on the sperm viability percentage value of Bali bull fresh semen. Duncan's significance difference test showed that the viability percentage value of the extender ratio at the 2-day storage on P0 (control) treatment of $67.62 \%$ was significantly different to the P1 treatment of $58.81 \%$, P2 of $61.49 \%$, and P3 of $63.78 \%$, but not significantly different to the P4 treatment of $66.02 \%$. The 3-day storage on $\mathrm{P0}$ (control) treatment of $65.07 \%$ was significantly different to the $\mathrm{P} 1$ treatment of 
$55.65 \%, \mathrm{P} 2$ of $58.43 \%$, and $\mathrm{P} 3$ of $60.92 \%$, but not significantly different to the P4 treatment of $63.55 \%$. This indicated that $70 \%$ coconut water and $30 \%$ egg yolk extender combination could be used as the sperm cell extenders because the results showed almost similar percentage of viability value to that of PO (control) treatment. This is in line with the Ducha et al.'s (2012) research that the best viability value of cow spermatozoa during storage is obtained from spermatozoa stored in above $20 \%$ egg yolk-based extenders. Lipoproteins and lecithin in egg yolk can maintain the cow sperm viability percentage value.

The results of variance indicated the Bali bull sperm viability percentage value. Observation data showed that the longer storage time decreased the sperm viability percentage value. Mardian et al. (2017) suggest that the length of storage for the sperm cells may decrease viability and motility value due to the increased lactic acid as the result of cell metabolic processes during storage. The increased lactic acid becomes toxic, causing the sperm death. It is in line with Rizal's (2009) research that the longer storage time decreases the food availability in the medium, resulting in the decreased sperm viability value. The viability percentage declines due to cold temperatures during storage, reduced energy availability in extenders, decreased $\mathrm{pH}$ because of increased lactic acid from sperm metabolism, and the presence of plasma membrane and acrosome damage (Pareira et al., 2010).

\section{CONCLUSION}

From the research results, it can be concluded that the extender ratio of $70 \%$ coconut water and $30 \%$ egg yolk was able to maintain the sperm viability percentage to survive on storage temperature of $5^{0} \mathrm{C}$ on the third day.

\section{REFERENCES}

1. Amirta, L. B. Tainturier, D. \& Anton, M. 2007. Use of Egg Compouns for Cryoprotectan of Spermatozoa, in Bioactive Egg Compouds. National Center For Biotechnology Information. 61:895-907.

2. Arifiantini, L. T. L. Yusuf, \& Yanti, D. 2005. Kaji Banding Kualitas Semen Beku Sapi Friesian Holstein Menggunakan Pengencer dari Berbagai Balai Inseminasi Buatan di Indonesia. Animal Production Vol.7(3) :168-176.

3. Arifiantini, R. I. \& Purwantara, B. 2010. Motility and viability of Frriesian Holstein Spermatozoa in Three Different Extender Stored at $5^{\circ} \mathrm{C}$. J Indonesian Trop Anim Agric Vol.35 (4) : 222-226.

4. Carla E., Paes, E., Cesar, A., \& Raphael C. 2008. Effects that bovine sperm cryopreservation using two different extenders has on sperm membranes and chromatin. Animal Reproduction Sciencie. Vol.104. (2) : 119-131.

5. Ducha, N, Susilawati, T. Aulanniam, Wahyuningsih S., \& Mulyoto P. 2012. Ultrastructure and Fertilizing Ability of Limousin Bull Sprem After Storage in Cep-2 Extender With and without Egg Yolk. Pakistan Journal of Biological Sciences, 15 : 979-985.

6. Garner, D.L. \& E.S.E. Hafez 2008. Spermatozoa and Plasma Semen. In Reproduction in Fram Animal. Hafez E.S.E. and B. Hafez (eds.). $7^{\text {th }}$ ed. Lippincott and Willams. Baltimore, Marryland, USA : 82-95.

7. Hadi U.P. \& Ilham P. 2002. Problem dan prospek Pengembagan Usaha Pembibitan sapi Potong di Indonesia. Jurnal Litbang Indonesia. Vol. 21 (2) :148-155.

8. Hastuti, D. 2008.. Tingkat keberhasilan Inseminasi Buatan Sapi Potong di Tinjau dari Angka Konsepsi dan Service Per Conseption. JIIP. Vol. 4 (1) : 12-20.

9. Hine, M. Burhanuddin \& Marawali A. 2014. Efektifitas Air Bual Lontar Dalam Mempertahankan Motilitas Viabilitas dan Daya Tahan Hidup Spermatozoa Sapi Bali. Jurnal Veteriner.Vol.15 (2) : 263-273.

10. Mardian, A. B., Zumarni dan Harap E. A. 2017. Kualitas Semen Cair Sapi Simental Menggunakan Larutan Isotonis Komersial Pada Konsentrasi dan Lama Penyimpanan Berbeda. Jurnal Peternakan Vol 14 (2) :(70-79) 
11. Pareira, G.R., E.G. Becker, L.C. Siquiera, R. Ferreira, C.K. Oliveira, \& P.B.D. Goncalves. 2010. Assessment of Bovine Spermatozoa Viability Using Different Cooling Protocols Prior to Cryopreservation. Italian Journal of Animal Science 9 : 403-407.

12. Rizal, M. 2009. Daya Hidup Spermatozoa Epididimis Sapi Bali Yang Dipreservasi Pada Suhu $3-5^{0}$ dalam Pengencer Tris Dengan Konsentrasi Laktosa Yang Berbeda. Journal JITV Vol. 14 (2) : 142-149.

13. Sulabda, 2010. Pengaruh Substitusi Air Kelapa Muda Dengan Pengencer Sitrat Kunig telur Terhadap Motilitas dan Persentase Hidup Spermatozoa Anjing. Buletin Veteriner Udayana Vol. 2 (2) : 109-117.

14. Zakiah, F. 2009. Penggunaan Air Kelapa Sebagai Penyimbang Fruktosa Dalam Pengencer Terhadap Kualitas Sperma Sapi Simmental. USU Repository, 2009. 